\title{
Review
}

\section{Zebrafish as a Model to Evaluate Nanoparticle Toxicity}

\author{
Enamul Haque ${ }^{1,2}$ and Alister C. Ward ${ }^{1,2, *}$ \\ 1 School of Medicine, Deakin University, Waurn Ponds, VIC 3216, Australia; md.haque@deakin.edu.au \\ 2 Centre for Molecular and Medical Research, Deakin University, Waurn Ponds, VIC 3216, Australia \\ * Correspondence: alister.ward@deakin.edu.au; Tel.: +61-3-5227-2041
}

Received: 13 June 2018; Accepted: 20 July 2018; Published: 23 July 2018

\begin{abstract}
Nanoparticles are increasingly being developed for in vivo use, from targeted drug delivery to diagnostics, where they have enormous potential, while they are also being used for a variety of applications that can result in environmental exposure for humans. Understanding how specific nanoparticles interact with cells and cell systems is essential to gauge their safety with respect to either clinical or environmental exposure. Zebrafish is being increasingly employed as a model to evaluate nanoparticle biocompatibility. This review describes this model and how it can be used to assess nanoparticle toxicity at multiple levels, including mortality, teratogenicity, immunotoxicity, genotoxicity, as well as alterations in reproduction, behavior and a range of other physiological readouts. This review also provides an overview of studies using this model to assess the toxicity of metal, metal oxide and carbon-based nanoparticles. It is anticipated that this information will inform research aimed at developing biocompatible nanoparticles for a range of uses.
\end{abstract}

Keywords: zebrafish; nanoparticles; nanotoxicity; biocompatibility

\section{Introduction}

\subsection{Nanoparticles}

According to the definitions of the International Organization for Standardization, American Society of Testing and Materials and National Institute of Occupational Safety and Health, particles with a diameter between 1 and $100 \mathrm{~nm}$ or fibers spanning the range 1-100 nm are termed as nanoparticles (NPs) [1]. Over the last decade, the synthesis, analysis and application of nanoparticles has grown exponentially, becoming an active area of intense innovation [2]. Recent advances allow for the synthesis of nanosized particles with multiple properties, referred to as multifunctional nanoparticles, which includes metal and metal oxides nanoparticles, fullerenes, carbon nanotubes (CNT), nano polymers and crystalline materials $[3,4]$.

\subsection{Applications of Nanoparticles}

NPs are being utilized for a wide range of applications. In manufacturing they are employed as chemically-inert additives, from fillers to pigments to anti-caking agents, but increasingly to create functional surfaces/membranes with catalytic, anti-microbial, UV protection, filtration and other diverse properties [5]. They are also fueling a new discipline of nanomedicine, lying at the intersection of chemistry, physics and medicine and focused on a range of biomedical applications. These include use as biosensors for nucleic acids, metabolites, proteins, drugs, pathogens and cancer cells by taking advantage of inherent optical, electrochemical, piezo-electric and photoluminescence properties $[5,6]$. NPs are also being used in a broad range of bioimaging, drug delivery, tissue engineering and other therapeutic applications, such as photoablation, which are facilitated by the accessibility of these small molecules throughout the body, and the ability to link with specific targeting modalities as well as carry a functional payload $[4,6,7]$. 


\subsection{Measuring Nanoparticle Toxicity}

Biomedical applications explicitly require nanoparticles that are non-toxic. However, toxicity is also an important consideration for nanoparticles used for manufacturing and other applications, since these can result in environmental exposure [2,8]. A number of different platforms are available to assess toxicity, ranging from in vitro cell culture assays to basic model organisms, such as sea urchin and daphnia, to advanced higher vertebrate models, like rodents and primates [9]. Cell lines and simple organisms are useful for cell-level toxicity and genotoxicity studies, but higher vertebrates are essential to detect complex physiological interactions. However, rodent models are high cost, have relatively slow and inaccessible embryo development, require substantial amounts of material for testing due to their relatively large size, and are accompanied by ethical concerns about their use-while primate models have similar issues, but to an even greater extent [9]. Therefore, small, low cost but sophisticated models are very attractive for the evaluation of in vivo nanotoxicity. In this context the zebrafish serves as a compelling, efficient and cost-effective alternative [10].

\section{Zebrafish as a Model}

\subsection{Overview}

The zebrafish (Danio rerio) is an established vertebrate model for the study of development and disease [11-16] and is being increasingly used for both pre-clinical studies and toxicological applications due to a range of favorable traits $[17,18]$. Zebrafish require relatively inexpensive housing, making them very cost-effective, and are small in size, reducing housing requirements as well as the quantity of agent required for testing $[11,16]$. They also exhibit a high fecundity rate, with a single female able to produce around 300 eggs, further underpinning their efficiency as a model [11,19]. The zebrafish and human genomes share $\sim 70 \%$ similarity $[20,21]$. There is also very good conservation of major developmental and physiological processes, with key organ systems, such the digestive, nervous and cardiovascular systems, similar to humans [22]. This largely underpins the extensive equivalence in response to pharmacological agents between the two species [23], with many zebrafish models mimicking human diseases both genetically and phenotypically [16].

\subsection{Zebrafish Development}

Zebrafish eggs are robust and develop externally, making them easy to manipulate and amenable to high-throughput applications. This is further augmented by the optical transparency of the developing zebrafish, which allows exquisite visual analysis, including of fluorescent and other markers [12,16]. Development is also incredibly rapid, with the basic zebrafish body plan well-established by $24 \mathrm{~h}$ post fertilization (hpf), with embryogenesis completed by $72 \mathrm{hpf}$ and most organs fully developed by $96 \mathrm{hpf}$ and reaching adulthood in around 3 months [12]. This makes them amenable to a wide variety of toxicological applications throughout their lifespan (Figure 1). 


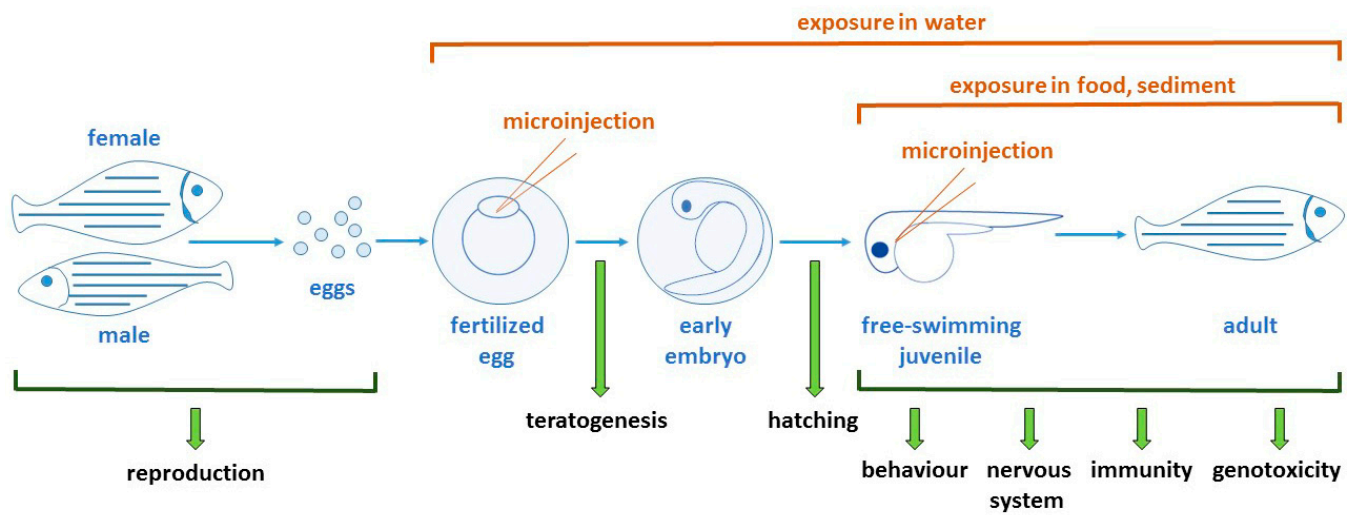

Figure 1. Toxicological studies performed in zebrafish. Schematic representation of zebrafish development, from spawning of embryos through their rapid development and hatching into free-swimming larvae and further growth and development into adults. Nanoparticles (NPs) can be administered via a variety of routes, including injection into eggs or specific sites on juveniles and adults, or alternatively administered in the water, sediment or food. The key assays used to examine toxicity in this model are indicated.

\section{Approaches for Measuring Nanoparticle Toxicity in Zebrafish}

\subsection{Assessing Teratogenic and Other Developmental Effects}

The rapidly developing, transparent and external embryos of zebrafish [24] are ideally suited for screening for agents that disrupt normal development, from the rapid cell divisions that follow fertilization, to the extensive morphogenesis that occurs during epiboly to the development of the body plan and its key organs and other structures $[25,26]$. Particularly sensitive to perturbation are the eye, brain, heart, notochord and fin, while visualization of the effects on pigmented cells, including red blood cells, as well as hatching and overall mortality, is very easy. For example, disrupted eye development and pigmentation was observed via simple light microscopy following exposure of zebrafish embryos to functionalized gold nanoparticles [27]. In addition, the dose- and time-dependent toxicity of silica NPs was able to be readily gauged by assessing mortality rates [28] and impacts on the cardiovascular system [29]. Furthermore, the enhanced biocompatibility of chitosan NPs compared to normal chitosan particles was evaluated by quantifying relative hatching [30].

\subsection{Immunotoxicity}

The immune system has been shown to be very sensitive to a variety of agents, including NPs, particularly the induction of an inflammatory response as well as associated accumulation and activation of neutrophils and macrophages [31]. For example, gold (Au) NPs have been shown to disrupt pathways involved in inflammatory and other immune responses [32], while silver (Ag) NPs caused immunotoxicity in adult zebrafish due to oxidative stress [33].

\subsection{Genotoxicity}

DNA is susceptible to damage following exposure to many chemical entities, which results in gene mutations and larger chromosomal alterations, collectively termed genotoxicity [34]. This can be assessed in embryos, larvae or adult tissues in a number of approaches, including quantitative RAPD-PCR methodology that has been used to demonstrate dose-dependent genotoxicity of $\mathrm{TiO}_{2}$ NPs [35], and comet assays for examining the impact of ferric oxide $\left(\mathrm{Fe}_{2} \mathrm{O}_{3}\right) \mathrm{NPs}$ [36].

\subsection{Reproduction Analysis}

The high fecundity rates of zebrafish are well suited to assessing the impact of agents on various aspects of reproduction, from egg production to fertilization rates to subsequent embryo viability. 
For example, reduced egg production and increased embryo mortality represent a hallmark of chronic exposure with $\mathrm{TiO}_{2}$ NPs [37], while in contrast Ag NPs mediated enhanced maturation of zebrafish oocytes due to increased oxidative stress and resultant follicle cell apoptosis [38].

\subsection{Neurotoxicity and Behavioral Analysis}

Zebrafish exhibit a range of complex behaviors that can be used as sensitive parameters to assess toxicity, including color preference, spatial recognition and locomotion $[39,40]$. The nervous system that underpins these behaviors, including the developing brain, is particularly vulnerable to oxidative stress because of its high energy demand, low level of antioxidants, and high cellular content of lipids and proteins. A range of NPs can trigger free radical activity at their surface, thereby creating oxidative stress at the site of particle deposition and translocation [41-43]. Neurotoxicity has been commonly noted for NPs that are able to reach the brain, where they can lead to neurodegeneration [44,45]. Behavioral effects have also been seen that are specific for particular NPs. For example, altered color preferences were found to be caused by silicon dioxide $\left(\mathrm{SiO}_{2}\right) \mathrm{NPs}$ [46], while locomotor activity was affected by cadmium telluride (CdTe) quantum dots [47]. More detailed analysis has identified enhanced neuron apoptosis and glial cell proliferation, along with altered gene expression, following exposure to titanium dioxide $\left(\mathrm{TiO}_{2}\right) \mathrm{NPs}$ [48].

\subsection{Other Approaches}

A range of additional techniques can be used to further understand potential toxicity, including a variety of high-content approaches [49], such as transcriptome analysis [36,50] and plasmonic spectroscopy [51]. Taking advantage of the optical transparency and genetic amenability of zebrafish, transgenic reporter lines have increased the ease and efficiency of toxicology studies [47,52]. Certain agents have inherent luminescent or fluorescent properties that can also be exploited to provide dynamic imaging of zebrafish embryos [53], including studies examining NP distribution in vivo [54,55].

\subsection{Comparison between Zebrafish and Mammalian Studies}

A number of studies have demonstrated that a variety of compounds tested in zebrafish embryos yielded similar results to those observed in rodents. This includes research showing comparable developmental toxicity for a series of 1,2,4-triazoles [56] and organotins [57], as well as correlations between zebrafish embryo LC50 (lethal concentration 50\%) values and rodent LD50 (lethal dose 50\%) values for a set of 60 compounds [49], although the latter study showed that the compound class influenced relative toxicity [49]. In a landmark study, a meta-analysis of toxicity testing in zebrafish of over 600 chemicals was performed, which compared aggregated toxicological end-points with outcomes observed in laboratory mammals. This demonstrated that for acute toxicity, there was a good correlation between zebrafish embryo LC50 values and LD50 values obtained across various laboratory mammals when the chemicals were administered via inhalation or injection, but not orally [58], which was consistent with other studies $[59,60]$. There was also a correlation between effects on zebrafish hatching and pre-natal loss in rabbits [58]. Furthermore, analysis of teratogens using zebrafish correctly ranked known mammalian teratogens [61,62]. Of note, zebrafish embryos were consistently more sensitive than mammalian systems to the agents tested [58,59].

\subsection{Standardization of Zebrafish Testing}

In light of the effectiveness of using zebrafish and other fish species for toxicity studies, test guidelines have been developed by the Organization for Economic Cooperation and Development (OECD). These include guidelines for the Fish Embryo Toxicity (FET) test [63], Fish: Juvenile Growth Test [64], and the adult-based Fish: Acute Toxicity Test [65]. The FET test has been validated by independent laboratory testing and has been shown to be a robust and reproducible methodology [66]. It has also been shown to have an excellent correlation with the Acute Toxicity Test in adults [67], 
and has been proposed to be a worthy range-finder prior to more extensive testing [68]. A recent study used the FET test to evaluate toxicity of methylxanthine drugs, which revealed a strong positive correlation between TC50 measurements of mortality, morphological defects and teratogenicity in zebrafish embryos and published mammalian LD50 values [69].

\section{Selected Nanotoxicology Studies in Zebrafish}

Zebrafish have been utilized for a myriad of nanotoxicology studies [36-38,48,70,71]. A summary of key studies involving the analysis of metal, metal oxide and carbon-based nanoparticles, particularly those related to shape, size and surface charge are discussed below, with relative toxicity summarized (Table 1).

Table 1. $\mathrm{LC}_{50}$ toxicity testing in zebrafish embryos and adults of nanoparticles detailed in this review and selected others.

\begin{tabular}{|c|c|c|c|c|c|}
\hline Nano Particle & Stage & $\mathrm{LC}_{50}(\mathrm{mg} / \mathrm{L})$ & Time & Teratogenicity & Reference \\
\hline \multirow{3}{*}{$\mathrm{Cu}$} & eggs & 24.0 & $48 \mathrm{~h}$ & Malformations, delayed hatching & [72] \\
\hline & \multirow{2}{*}{ adults } & 4.2 & $48 \mathrm{~h}$ & $\mathrm{~N} / \mathrm{A}$ & [72] \\
\hline & & 1.5 & $48 \mathrm{~h}$ & $\mathrm{~N} / \mathrm{A}$ & [73] \\
\hline Chitosan & eggs & 280 & $96 \mathrm{~h}$ & Malformations & [30] \\
\hline \multirow{2}{*}{$\mathrm{Au}$} & eggs & $>200$ & $48 \mathrm{~h}$ & None & [72] \\
\hline & adults & $>200$ & $48 \mathrm{~h}$ & $\mathrm{~N} / \mathrm{A}$ & [72] \\
\hline \multirow{3}{*}{$\mathrm{Ag}$} & \multirow{2}{*}{ eggs } & 2.7 & $48 \mathrm{~h}$ & Malformations & [72] \\
\hline & & 1.2 & $96 \mathrm{~h}$ & Malformations & [74] \\
\hline & adults & 2.9 & $48 \mathrm{~h}$ & $\mathrm{~N} / \mathrm{A}$ & [72] \\
\hline $\mathrm{Cd} / \mathrm{Te} \mathrm{QDs}$ & eggs & $186(\mathrm{nM})$ & $120 \mathrm{~h}$ & Malformations, delayed hatching & [75] \\
\hline \multirow{2}{*}{$\mathrm{TiO}_{2}$} & eggs & $>1600$ & $48 \mathrm{~h}$ & Premature hatching & [72] \\
\hline & adults & $>1600$ & $48 \mathrm{~h}$ & $\mathrm{~N} / \mathrm{A}$ & [72] \\
\hline \multirow{2}{*}{$\mathrm{ZnO}$} & \multirow{2}{*}{ eggs } & $3.5-9.1$ & $120 \mathrm{~h}$ & None & [76] \\
\hline & & 1.8 & $96 \mathrm{~h}$ & Delayed hatching & [77] \\
\hline \multirow{3}{*}{$\mathrm{MgO}$} & \multirow{2}{*}{ eggs } & $>3200$ & $48 \mathrm{~h}$ & None & [72] \\
\hline & & 428 & $96 \mathrm{~h}$ & Delayed hatching & [78] \\
\hline & adults & 140 & $48 \mathrm{~h}$ & $\mathrm{~N} / \mathrm{A}$ & [72] \\
\hline \multirow{2}{*}{$\mathrm{Fe}_{2} \mathrm{O}_{3}$} & eggs & $>1600$ & $48 \mathrm{~h}$ & None & [72] \\
\hline & adults & $>1600$ & $48 \mathrm{~h}$ & $\mathrm{~N} / \mathrm{A}$ & [72] \\
\hline \multirow{3}{*}{$\mathrm{NiO}$} & eggs & 1700 & $48 \mathrm{~h}$ & None & [72] \\
\hline & \multirow{2}{*}{ adults } & 760 & $48 \mathrm{~h}$ & $\mathrm{~N} / \mathrm{A}$ & [72] \\
\hline & & 45 & $30 \mathrm{~d}$ & $\mathrm{~N} / \mathrm{A}$ & [79] \\
\hline \multirow{3}{*}{$\mathrm{CuO}$} & \multirow{2}{*}{ eggs } & 960 & $48 \mathrm{~h}$ & None & [72] \\
\hline & & 175 & $48 \mathrm{~h}$ & None & [80] \\
\hline & adults & 400 & $48 \mathrm{~h}$ & $\mathrm{~N} / \mathrm{A}$ & [72] \\
\hline \multirow{3}{*}{ Fullerene } & \multirow{2}{*}{ eggs } & $>200$ & $48 \mathrm{~h}$ & None & [72] \\
\hline & & 1.5 & $96 \mathrm{~h}$ & Reduced hatching & [81] \\
\hline & adults & $>200$ & $48 \mathrm{~h}$ & $\mathrm{~N} / \mathrm{A}$ & [72] \\
\hline \multirow{3}{*}{ CNTs } & \multirow{2}{*}{ eggs } & $>200$ & $48 \mathrm{~h}$ & None & [72] \\
\hline & & $>360$ & $96 \mathrm{~h}$ & None & [82] \\
\hline & adults & $>200$ & $48 \mathrm{~h}$ & $\mathrm{~N} / \mathrm{A}$ & [72] \\
\hline
\end{tabular}




\subsection{Metal Nanoparticles}

\subsubsection{Gold}

Among metal nanoparticles, Au NPs have been the most widely studied in biomedicine, with key applications as drug carriers [83] and as diagnostic agents [84]. However, Au NPs can cause cytotoxicity in humans $[85,86]$. As a consequence, zebrafish has become increasingly used as an in vivo model to evaluate the toxicity of Au NPs.

Food containing Au NPs (12 and $50 \mathrm{~nm}$ ) elicited a variety of cellular dysfunctions as well as genome alterations in adult zebrafish that were dependent on size, concentration and exposure time [87]. Chronic exposure of zebrafish to sediment containing $14 \mathrm{~nm}$ Au NPs also resulted in genome modification in various adult tissues, probably related to increased oxidative stress [88]. Au NPs were found to accumulate within tissues, suggesting the potential for higher toxicity compared with ionic Au. This was supported by other work that demonstrated 10-50 nm Au NPs could induce strand breaks in zebrafish ovaries, in addition to other cell types [89].

Surface charge functionalization has been identified as a critical determinant of toxicity. In one key study, Au NPs functionalized with positively-charged N,N,N-triethylammoniumethanol (TMAT) caused significant mortality, but elicited negligible malformations, whereas those functionalized with negatively-charged 2-mercaptoethanatesulfonate (MES) substantially increased the incidence of malformations, but did not result in significant mortality within the five-day exposure period. Neutral 2,2-mercaptoethoxyethoxyethanol (MEEE) and 2,2-mercaptoethoxyethanol (MEE) functionalized Au NPs did not elicit adverse effects even at higher concentrations of up to $250 \mathrm{ppm}$. A related study additionally found that exposure to either positively and negatively charged Au NPs resulted in behavioral abnormalities, including hypo-locomotor activity [90]. Kim et al. further showed that $1.3 \mathrm{~nm}$ TMAT-functionalized Au NPs caused abnormal eye development, with altered pigmentation and neuronal damage and concomitant behavioral changes [27]. These effects correlated with the ability of charged Au NPs to mediate inflammatory and altered immune effects [32].

Shape represents another important factor mediating the effects of Au NPs. The toxicity and biodistribution of fluorescently-labeled Au NPs of different shapes were examined in adult zebrafish [91]. Rod-shaped Au NPs exhibited enhanced uptake and clearance, while star-shaped Au NPs in contrast displayed slower uptake but longer sequestration in comparison to rod-shaped or spherical particles.

This study also showed that the choice of linker-polyethylene glycol (PEG) or mannose-capped-also had a significant effect [91]. Other research with peptide-capped Au NPs showed that the terminal modification was important, with the presence of terminal histidines being more toxic than tryptophans, with methionine conferring the least toxicity [92]. In addition, co-incubation of zebrafish embryos with Au NPs and a surfactant (polysorbate 20) resulted in increased uptake and toxicity [93]. Together this suggests that the overall shape and surface chemistry of the Au NPs are key determinants of biocompatibility.

\subsubsection{Silver}

Ag NPs have also been extensively studied, with broad applications as therapeutic agents [94], antimicrobial agents [95], drug delivery systems [96] and biosensors [96].

Exposure of zebrafish to Ag NPs during early development elicited a range of toxicities, including a reduction in heart rate, damage to neuromast hair cells and more modest but statistically significant increases in both mortality and teratogenicity [97]. Another study demonstrated that low concentrations of 10-20 nm Ag NPs ( $<5 \mathrm{mg} / \mathrm{L}$ ) had little impact on normal embryonic development, but higher concentrations resulted in significant effects on the development of mesodermal and ectodermal tissues, possibly due to delayed or inhibited cell division [98]. Exposure of adult zebrafish to Ag NPs resulted in localization in the gills and liver, where they caused oxidative stress and immunotoxicity [33]. 
The size-dependence of Ag NP-mediated toxicity is still debatable. One study reported similar mortality for zebrafish embryos treated with Ag NPs across a size range of 3-200 nm [99]. In contrast, Lee et al. showed that Ag NPs with a particle size of 30-72 nm were able to selectively enter zebrafish embryos through chorionic pores via random Brownian motion and caused more potent toxic effects [70]. In another study, Ag NPs were found to impact on neural development of zebrafish embryos in a size-dependent manner. In this case, $4 \mathrm{~nm} \mathrm{Ag} \mathrm{NPs} \mathrm{were} \mathrm{taken} \mathrm{up} \mathrm{more} \mathrm{efficiently} \mathrm{than}$ $10 \mathrm{~nm}$-sized particles, with the head of the exposed zebrafish embryos able to accumulate more $\mathrm{Ag}$ NPs than the trunk [100].

The charge characteristics of Ag NPs has also been demonstrated to be an important determinant of toxicity. Investigation of $\sim 12 \mathrm{~nm}$ Ag NPs functionalized with peptides of different charge revealed that positively-charged Ag NPs were the most biocompatible, with the extent of deformity and level of mortality greater in those embryos exposed to NPs with a negatively-charged peptide coating and greatest for those with a highly negatively-charged peptide coating [101].

Ag NPs of several different shapes were all shown to induce oxidative stress, but plate shaped Ag NPs were more toxic than spherical and wire-like shaped forms [102,103]. Interestingly, these effects correlated with the presence of surface defects rather than Ag shedding [102]. Coating with cysteine [102] or sulfidation [104] resulted in Ag NPs that elicited reduced oxidative stress in embryos or adults, respectively. Other studies have further demonstrated that embryonic toxicity of Ag NPs was augmented by exposure to simulated solar light [105]. Collectively, this suggests a complex interplay of factors, where a range of physiochemical properties underpin biocompatibility.

\subsubsection{Cadmium-Based Quantum Dots}

Quantum dots (QDs) have been extensively employed for biological and medical imaging because of their small size and bright fluorescence, with broad absorption spectra, narrow emission spectra and high photostability [101,106-108]. Cadmium selenide (CdSe) and CdTe nanocrystals represent two of the most commonly utilized QDs for biological applications, with their extremely bright fluorescent properties making them powerful labelling agents for diverse in vivo applications. Several studies have shown CdSe QDs to be well tolerated with only modest toxicity even when directly injected into embryos at relatively high concentrations $[47,109]$. However, exposure of CdTe QDs to zebrafish embryos lead to a range of developmental and behavioral disturbances [75].

\subsection{Metal Oxides}

Metal oxide NPs, and particularly those based on $\mathrm{TiO}_{2}$, are widely used in a range of products, including paint, food and personal care products $[110,111]$. Due to concerns over the possible consequences of environmental exposure, their biocompatibility has been extensively studied using zebrafish.

\subsection{1. $\mathrm{TiO}_{2}$}

Low dose $(1 \mathrm{mg} / \mathrm{L})$ exposure of zebrafish embryos to $\mathrm{TiO}_{2}$ NPs failed to induce major developmental malformations [112], although several groups have demonstrated that $\mathrm{TiO}_{2} \mathrm{NPs}$ cause premature hatching in a dose-dependent manner [113,114]. In addition, higher doses of $\mathrm{TiO}_{2}$ NPs can lead to embryonic malformation and death [45]. Another study demonstrated that $\mathrm{TiO}_{2} \mathrm{NPs}$ were able to absorb photons and produce electron-hole pairs that interact with water and oxygen to form reactive oxygen species that were toxic to zebrafish larvae [115]. Chronic exposure of adult zebrafish to $\mathrm{TiO}_{2} \mathrm{NPs}$ at low concentrations $(<4 \mathrm{mg} / \mathrm{L})$ for 6 months was also associated with low toxicity, as determined by mortality rate. However, at higher concentration these NPs were found to accumulate in different parts of the fish, including the gill, liver, heart and brain [116]. High level exposure can also lead to genotoxic effects [35].

However, the major effect of $\mathrm{TiO}_{2} \mathrm{NPs}$ is neurotoxicity. Even low levels of $\mathrm{TiO}_{2} \mathrm{NPs}_{\mathrm{N}}$ showed impacts on embryonic neurogenesis and neuronal differentiation observed [112], while exposure of 
larvae to $\mathrm{TiO}_{2}$ NPs significantly affected swimming parameters, including average and maximum velocity [117]. $\mathrm{TiO}_{2}$ NPs were able to cross the blood-brain barrier to damage the brain [45]. Chronic exposure of adult zebrafish to low dose $\mathrm{TiO}_{2}$ NPs for 45 days led to reduced levels of neurotransmitters and consequent changes in behavior, as well as histopathological changes in the zebrafish brain, which were associated with dose-dependent increases in nitric oxide levels [48]. Other researchers have compared the effect of bulk $\mathrm{TiO}_{2}$ and $\mathrm{TiO}_{2} \mathrm{NPs}$ on the zebrafish brain, which revealed that $\mathrm{TiO}_{2} \mathrm{NPs}$ were more toxic than bulk $\mathrm{TiO}_{2}$ due to enhanced lipid oxidation and degradation [118].

\subsubsection{Zinc Oxide $(\mathrm{ZnO})$}

Zinc oxide $(\mathrm{ZnO}) \mathrm{NPs}(20 \mathrm{~nm})$ have also been shown to cause delayed development and inhibition of hatching in zebrafish embryos but only at higher concentrations $(>0.1 \mathrm{mg} / \mathrm{L})[77,119]$. Again, surface properties and shape appear to be important. Polymer-coated ZnO NPs were shown to be more biocompatible than spherical $\mathrm{ZnO}$, with leaf-shaped $\mathrm{ZnO}$ NPs having the greatest impact on hatching [120]. In another study comparing different shapes of ZnO NPs, nanosticks were found to be more toxic than nanospheres and cuboidal submicron particles with respect to hatching and overall mortality [121]. However, similar results were observed between $\mathrm{ZnO}$ NPs and bulk ZnO, suggesting that leaching of the metal oxide may be a key factor in mediating the effects of ZnO NPs [77]. Co-incubation with humic acid was able to suppress the impact of the released zinc [119].

\subsubsection{Other Metal Oxides}

A number of studies have shown that other metal oxide NPs elicit variable toxicity. For example, magnesium oxide $(\mathrm{MgO}) \mathrm{NPs}(20 \mathrm{~nm})$ decreased hatching rate and survival of zebrafish embryos in a dose-dependent manner, leading to various types of malformations [78]. $\mathrm{Fe}_{2} \mathrm{O}_{3} \mathrm{NPs}$ caused severe deformities in embryos [122] and elicited strong genotoxic effects in adult zebrafish [36]. Others have observed that NPs based on cupric oxide $(\mathrm{CuO})$ and nickel oxide $(\mathrm{NiO})$ also interfered with hatching, whereas those utilizing cobalt oxide $\left(\mathrm{Co}_{3} \mathrm{O}_{4}\right)$ [123] or aluminum oxide $\left(\mathrm{Al}_{2} \mathrm{O}_{3}\right)$ [77] were relatively inert.

\subsection{Carbon Based Nanoparticles}

Carbon-based nanomaterials have attracted increasing interest in the field of biomedical research, including as drug delivery systems, tissue scaffold reinforcements and cellular sensors [124]. Carbon NPs are considered particularly promising due to their low toxicity compared to other NPs [125]. In the last few years, the toxicity of different carbon NPs have been evaluated using zebrafish as a model, such as fullerenes, carbon nanoparticles, carbon nanotubes (CNT), graphene QDs and carbon QDs (C-dots).

\subsubsection{Fullerenes}

Fullerenes are allotropes of carbon discovered in 1985 [126] that have been widely evaluated for biomedical applications, such as drug and gene delivery [127], bioimaging [128] and quenching of reactive oxygen species [128]. Analysis in zebrafish has shown that fullerenes exhibit toxicity that is related to their surface chemistry. Exposure of embryos to $C_{60}$ or $C_{70}$ fullerenes at $200 \mathrm{ppb}$ delayed development and resulted in specific caudal fin malformation and significant pericardial edema, with $>200$ ppm $\mathrm{C}_{60}$ or $\mathrm{C}_{70}$ leading to $100 \%$ mortality. In contrast, exposure to $>2500 \mathrm{ppb}_{60}(\mathrm{OH})_{24}$ was required to induce fin malformations and pericardial edema, with significant mortality only observed at concentrations of $>4000 \mathrm{ppb}$ [129]. Another study of water soluble fullerenes indicated that positively-charged fullerenes showed enhanced toxicity compared to negatively-charged fullerenes with similar structures. Toxicity was shown to vary considerably between the negatively-charged fullerenes from very low to moderate, depending on structural features [130]. Kuznetsova et al. showed phosphatidylcholine-based phospholipid NPs containing $C_{60}$ elicited low toxicity on zebrafish embryos [131]. Photons appear to exacerbate toxicity, since reducing light levels during exposure to 
$\mathrm{C}_{60}$ (at 200-300 ppb) significantly decreased mortality as well as the incidence of fin malformations and pericardial edema [132]. Other research has suggested that water-soluble fullerenes may protect against apoptotic cell death [130]. This was supported by a study investigating a $\mathrm{C}_{60}$ fullerene based derivative (dendrofullerene) containing 18 carboxylic groups, which was able to reduce radiation-induced nerve cell damage through its actions as a free-radical scavenger [133]. Multi-shell fullerene structures, known as nano-onions, demonstrate good biocompatibility, with little toxicity and homogenous biodistribution in zebrafish larvae [134].

\subsubsection{Carbon Nanotubes}

Carbon nanotubes (CNTs) have attracted intense interest for various biomedical applications due to their distinctive chemical and physical characteristics [124]. These characteristics make CNTs promising candidates for the delivery of chemotherapeutic agents, including paclitaxel and doxorubicin, small interfering RNAs, genes and antibodies [135,136].

Pristine CNTs have been shown to have high biocompatibility, with single-walled (SW), multi-walled (MW) CNTs or carboxylated MW pristine CNTs having little effect on embryo viability and development, even at high concentrations (200 ug/mL) [137]. In another study SW CNTs functionalized by polyethylene glycol increased mortality, delayed hatching and decreased total larval length only at the highest concentration tested (1 ppm), but with no genotoxicity observed and no evidence of the nanotubes being taken up by tissues [138]. Another group found that the length of CNTs was an important determinant of toxicity with longer CNTs causing distinctive cellular and molecular changes [139].

Exposure of adult zebrafish to MW CNT (diameter $500 \mathrm{~nm}$ ) caused reversible inflammation in the gills, but again no genotoxicity was seen [140]. Another study showed that MW CNTs were able to accumulate in zebrafish [141], while Li et al. demonstrated that exposure to CNTs can result in alterations in the brain and gonads [142].

\subsubsection{Carbon/Graphene Quantum Dots}

C-dots are a type of quasi-spherical carbon material with a diameter of $<10 \mathrm{~nm}$ [143], whereas graphene QDs (GQDs) represent multiple layers of graphene with a size of $<30 \mathrm{~nm}[144,145]$. Both C-dots and GQDs have emerged as superior universal fluorophores due to their unique combination of excellent photostability, small size and highly tunable photoluminescence, being effective in photon-harvesting in the short-wavelength region because of $\pi-\pi^{*}$ transition of $\mathrm{C}=\mathrm{C}$ bonds [146], with a variety of imaging applications [147]. C-dots and GQDs are also attractive for drug/gene delivery [148-151] due to their low toxicity, a consequence of the predominance of inert carbon rather than more reactive hydrogen, nitrogen and oxygen in their make-up [150,152]. However, C-dots and GQDs do contain $-\mathrm{OH},-\mathrm{NH}_{2},>\mathrm{C}=\mathrm{O}$ and $-\mathrm{COOH}$ functional groups on their surface, which increase water solubility [143], as well as assisting in covalent bond formation with antibody, chemotherapeutic agent or other biochemical entity $[153,154]$, which can be combined with their florescence properties (Figure 2) for multi-purpose theranostic applications.

C-dots have been shown to exhibit higher biocompatibility than other NPs [55]. N-doped C-dots synthesized from BSA were well tolerated by zebrafish embryos immersed in them at concentrations of $6 \mathrm{mg} / \mathrm{L}$ and retained fluorescence for up to 2 days, highlighting their low toxicity and stable fluorescence emission [155]. In another study, embryos exposed to C-dots showed normal development at concentrations of $2 \mathrm{mg} / \mathrm{L}$ (soaking) or $1.5 \mathrm{mg} / \mathrm{mL}$ (injection). However, at higher concentrations, delayed development, inhibition of pigmentation, pericardial edema, and delayed hatching were observed. GQDs also exhibited high biocompatibility, being readily excreted from adult zebrafish without affecting growth significantly at a concentration lower than $2 \mathrm{mg} / \mathrm{mL}$ [54]. The GQDs were found to accumulate in the digestive system, while the blood, muscle and other tissue showed no obvious photoluminescence signal. 


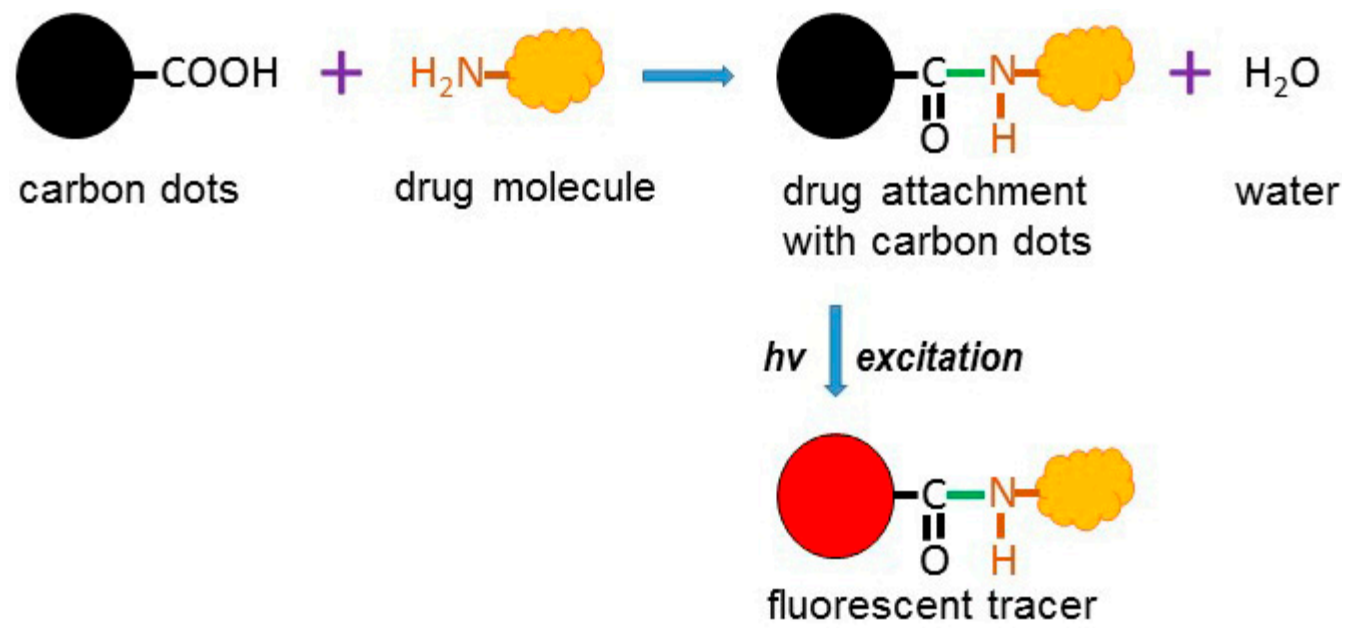

Figure 2. Carbon nanodot-based drug delivery and tracking. Schematic representation showing conjugation of carbon nanodots with drug molecules, and subsequent excitation to generate agents that act simultaneously as fluorescence tracers and drug delivery vehicles.

\section{Conclusions}

The nanotechnology industry is already large; it was estimated to be worth $\$ 39.2$ billion in 2016 [156], and is growing rapidly. To facilitate this, efficient and effective testing of new products is essential. Zebrafish represent an excellent in vivo model for testing nanoparticle toxicity and biocompatibility. They are low cost and easy to maintain, and able to test agents efficiently via multiple routes of exposure, including directly in the water, which is especially relevant for environmental toxicology applications. In addition, specific physiological impacts can be assessed at multiple stages of development. In this review, the toxicity of different metal and carbon-based NPs has been described, identifying a range of parameters regarding exposure (concentration, route, length, life-stage, presence of other molecules) and of physiochemical properties of the NPs (size, shape, surface charge/chemistry) that impact on their biocompatibility.

There is now a growing consensus advocating the greater use of zebrafish models to reduce reliance on rodent testing for financial, ethical and biological reasons [31]. Indeed, toxicity and safety testing in zebrafish has been accepted by the Federal Drug Administration for new drug approval [25]. This will be greatly augmented by standardization of delivery protocols, methods of analysis and strains of zebrafish used. Zebrafish also have great potential for pre-clinical studies and so represent an ideal model to assist the further development of NPs as therapeutic agents, such as testing mitigation strategies when a promising NP agent exhibits toxicity.

Author Contributions: Both authors contributed to Writing, including both Original Draft Preparation and Review \& Editing.

Funding: E.H. was supported by an Alfred Deakin Postdoctoral Research Fellowship, funded by Deakin University.

Conflicts of Interest: The authors declare no conflict of interest.

\section{References}

1. Horikoshi, S.; Serpone, N. Microwaves in Nanoparticle Synthesis: Fundamentals and Applications; John Wiley \& Sons: Hoboken, NJ, USA, 2013.

2. De Crozals, G.; Bonnet, R.; Farre, C.; Chaix, C. Nanoparticles with multiple properties for biomedical applications: A strategic guide. Nano Today 2016, 11, 435-463. [CrossRef]

3. Seaton, A.; Tran, L.; Aitken, R.; Donaldson, K. Nanoparticles, human health hazard and regulation. J. $R$. Soc. Interface 2009, 7, S119-S129. [CrossRef] [PubMed] 
4. McNamara, K.; Tofail, S.A. Biomedical applications of nanoalloys. In Nanoalloys: From Fundamentals to Emergent Applications; Elsevier Inc.: Amsterdam, The Netherlands, 2013; pp. 345-371.

5. Stark, W.J.; Stoessel, P.R.; Wohlleben, W.; Hafner, A. Industrial applications of nanoparticles. Chem. Soc. Rev. 2015, 44, 5793-5805. [CrossRef] [PubMed]

6. Das, S.; Mitra, S.; Khurana, S.M.P.; Debnath, N. Nanomaterials for biomedical applications. Front. Life Sci. 2013, 7, 90-98. [CrossRef]

7. McNamara, K.; Tofail, S.A. Nanosystems: The use of nanoalloys, metallic, bimetallic, and magnetic nanoparticles in biomedical applications. Phys. Chem. Chem. Phys. 2015, 17, 27981-27995. [CrossRef] [PubMed]

8. Friedman, A.D.; Claypool, S.E.; Liu, R. The smart targeting of nanoparticles. Curr. Pharm. Des. 2013, 19, 6315-6329. [CrossRef] [PubMed]

9. Gad, S.C. Animal Models in Toxicology; CRC Press: Boca Raton, FL, USA, 2006.

10. Chakraborty, C.; Sharma, A.R.; Sharma, G.; Lee, S.-S. Zebrafish: A complete animal model to enumerate the nanoparticle toxicity. J. Nanobiotech. 2016, 14, 65. [CrossRef] [PubMed]

11. Westerfield, M. The Zebrafish Book: A Guide for the Laboratory Use of Zebrafish (Brachydanio Rerio); University of Oregon Press: Eugene, OR, USA, 1995.

12. Stainier, D.Y.; Fishman, M.C. The zebrafish as a model system to study cardiovascular development. Trends Cardiovasc. Med. 1994, 4, 207-212. [CrossRef]

13. Granato, M.; Nüsslein-Volhard, C. Fishing for genes controlling development. Curr. Opin. Genet. Dev. 1996, 6, 461-468. [CrossRef]

14. Haffter, P.; Granato, M.; Brand, M.; Mullins, M.C.; Hammerschmidt, M.; Kane, D.A.; Odenthal, J.; Van Eeden, F.; Jiang, Y.-J.; Heisenberg, C.-P. The identification of genes with unique and essential functions in the development of the zebrafish, Danio rerio. Development 1996, 123, 1-36. [PubMed]

15. Talbot, W.S.; Hopkins, N. Zebrafish mutations and functional analysis of the vertebrate genome. Genes Dev. 2000, 14, 755-762. [PubMed]

16. Dooley, K.; Zon, L.I. Zebrafish: A model system for the study of human disease. Curr. Opin. Genet. Dev. 2000, 10, 252-256. [CrossRef]

17. Strähle, U.; Scholz, S.; Geisler, R.; Greiner, P.; Hollert, H.; Rastegar, S.; Schumacher, A.; Selderslaghs, I.; Weiss, C.; Witters, H. Zebrafish embryos as an alternative to animal experiments-A commentary on the definition of the onset of protected life stages in animal welfare regulations. Reprod. Toxicol. 2012, 33, 128-132. [CrossRef] [PubMed]

18. Chakraborty, C.; Agoramoorthy, G. Why zebrafish? Rivista di Biologia 2010, 103, 25. [PubMed]

19. Ribas, L.; Piferrer, F. The zebrafish (Danio rerio) as a model organism, with emphasis on applications for finfish aquaculture research. Rev. Aquacult. 2014, 6, 209-240. [CrossRef]

20. Howe, K.; Clark, M.D.; Torroja, C.F.; Torrance, J.; Berthelot, C.; Muffato, M.; Collins, J.E.; Humphray, S.; McLaren, K.; Matthews, L. The zebrafish reference genome sequence and its relationship to the human genome. Nature 2013, 496, 498-503. [CrossRef] [PubMed]

21. Kettleborough, R.N.; Busch-Nentwich, E.M.; Harvey, S.A.; Dooley, C.M.; de Bruijn, E.; van Eeden, F.; Sealy, I.; White, R.J.; Herd, C.; Nijman, I.J. A systematic genome-wide analysis of zebrafish protein-coding gene function. Nature 2013, 496, 494-497. [CrossRef] [PubMed]

22. Hsu, C.-H.; Wen, Z.-H.; Lin, C.-S.; Chakraborty, C. The zebrafish model: Use in studying cellular mechanisms for a spectrum of clinical disease entities. Curr. Neurovasc. Res. 2007, 4, 111-120. [CrossRef] [PubMed]

23. Peterson, R.T.; Fishman, M.C. Discovery and use of small molecules for probing biological processes in zebrafish. Meth. Cell Biol. 2004, 76, 569-591.

24. Kimmel, C.B.; Ballard, W.W.; Kimmel, S.R.; Ullmann, B.; Schilling, T.F. Stages of embryonic development of the zebrafish. Dev. Dyn. 1995, 203, 253-310. [CrossRef] [PubMed]

25. He, J.H.; Gao, J.M.; Huang, C.J.; Li, C.Q. Zebrafish models for assessing developmental and reproductive toxicity. Neurotoxicol. Teratol. 2014, 42,35-42. [CrossRef] [PubMed]

26. Nishimura, Y.; Inoue, A.; Sasagawa, S.; Koiwa, J.; Kawaguchi, K.; Kawase, R.; Maruyama, T.; Kim, S.; Tanaka, T. Using zebrafish in systems toxicology for developmental toxicty testing. Congenit. Abnorm. 2016, 56, 18-27. [CrossRef] [PubMed]

27. Kim, K.-T.; Zaikova, T.; Hutchison, J.E.; Tanguay, R.L. Gold nanoparticles disrupt zebrafish eye development and pigmentation. Toxicol. Sci. 2013, 133, 275-288. [CrossRef] [PubMed] 
28. Duan, J.; Yu, Y.; Shi, H.; Tian, L.; Guo, C.; Huang, P.; Zhou, X.; Peng, S.; Sun, Z. Toxic effects of silica nanoparticles on zebrafish embryos and larvae. PLoS ONE 2013, 8, e74606. [CrossRef] [PubMed]

29. Paatero, I.; Casals, E.; Niemi, R.; Ozliseli, E.; Rosenholm, J.M.; Sahlgren, C. Analyses in zebrafish embryos reveal that nanotoxicity profiles are dependent on surface-functionalization controlled penetrance of biological membranes. Sci. Rep. 2017, 7, 8423. [CrossRef] [PubMed]

30. Wang, Y.; Zhou, J.; Liu, L.; Huang, C.; Zhou, D.; Fu, L. Characterization and toxicology evaluation of chitosan nanoparticles on the embryonic development of zebrafish, Danio rerio. Carbohydr. Polym. 2016, 141, 204-210. [CrossRef] [PubMed]

31. Johnston, H.J.; Verdon, R.; Gillies, S.; Brown, D.M.; Fernandes, T.F.; Henry, T.B.; Rossi, A.G.; Tran, L.; Tucker, C.; Tyler, C.R.; et al. Adoption of in vitro systems and zebrafish embryos as alternative models for reducing rodent use in assessments of immunological and oxidative stress responses to nanomaterials. Crit. Rev. Toxicol. 2018, 48, 252-271. [CrossRef] [PubMed]

32. Truong, L.; Tilton, S.C.; Zaikova, T.; Richman, E.; Waters, K.M.; Hutchison, J.E.; Tanguay, R.L. Surface functionalities of gold nanoparticles impact embryonic gene expression responses. Nanotoxicology 2013, 7, 192-201. [CrossRef] [PubMed]

33. Krishnaraj, C.; Harper, S.L.; Yun, S.I. In vivo toxicological assessment of biologically synthesized silver nanoparticles in adult zebrafish (Danio rerio). J. Hazard. Mater. 2016, 301, 480-491. [CrossRef] [PubMed]

34. Bolognesi, C. Genotoxicity of pesticides: A review of human biomonitoring studies. Mutat. Res. Rev. Mutat. Res. 2003, 543, 251-272. [CrossRef]

35. Rocco, L.; Santonastaso, M.; Mottola, F.; Costagliola, D.; Suero, T.; Pacifico, S.; Stingo, V. Genotoxicity assessment of $\mathrm{TiO}_{2}$ nanoparticles in the teleost Danio rerio. Ecotoxicol. Environ. Saf. 2015, 113, 223-230. [CrossRef] [PubMed]

36. Villacis, R.A.R.; Filho, J.S.; Pina, B.; Azevedo, R.B.; Pic-Taylor, A.; Mazzeu, J.F.; Grisolia, C.K. Integrated assessment of toxic effects of maghemite $\left(\mathrm{g}-\mathrm{Fe}_{2} \mathrm{O}_{3}\right)$ nanoparticles in zebrafish. Aquat. Toxicol. 2017, 191, 219-225. [CrossRef] [PubMed]

37. Wang, J.; Zhu, X.; Zhang, X.; Zhao, Z.; Liu, H.; George, R.; Wilson-Rawls, J.; Chang, Y.; Chen, Y. Disruption of zebrafish (Danio rerio) reproduction upon chronic exposure to $\mathrm{TiO}_{2}$ nanoparticles. Chemosphere 2011, 83, 461-467. [CrossRef] [PubMed]

38. Chen, S.X.; Yang, X.Z.; Deng, Y.; Huang, J.; Li, Y.; Sun, Q.; Yu, C.-P.; Zhu, Y.; Hong, W.S. Silver nanoparticles induce oocyte maturation in zebrafish (Danio rerio). Chemosphere 2017, 170, 51-60. [CrossRef] [PubMed]

39. MacPhail, R.C.; Hunter, D.L.; Irons, T.D.; Padilla, S. Locomotion and behavioral toxicity in larval zebrafish: Background, methods, and data. Zebrafish Meth. Assess. Drug Saf. Toxicol. 2011, 151-164. [CrossRef]

40. Huang, Y.; Zhang, J.; Han, X.; Huang, T. The use of zebrafish (Danio rerio) behavioral responses in identifying sublethal exposures to deltamethrin. Int. J. Environ. Res. Public Health 2014, 11, 3650-3660. [CrossRef] [PubMed]

41. Sato, Q.; Zhang, Y.; Kusaka, K.; Donaldson, K.; Nakakuki, N.; Kohyama, K. Differences in the extent of inflammation caused by intratracheal exposure to three ultrafine metals: Role of free radicals. J. Toxicol. Environ. Health Part A 1998, 53, 423-438.

42. Dellinger, B.; Pryor, W.A.; Cueto, R.; Squadrito, G.L.; Hegde, V.; Deutsch, W.A. Role of free radicals in the toxicity of airborne fine particulate matter. Chem. Res. Toxicol. 2001, 14, 1371-1377. [CrossRef] [PubMed]

43. Li, N.; Sioutas, C.; Cho, A.; Schmitz, D.; Misra, C.; Sempf, J.; Wang, M.; Oberley, T.; Froines, J.; Nel, A. Ultrafine particulate pollutants induce oxidative stress and mitochondrial damage. Environ. Health Perspect. 2003, 111, 455-460. [CrossRef] [PubMed]

44. Win-Shwe, T.-T.; Fujimaki, H. Nanoparticles and neurotoxicity. Int. J. Mol. Sci. 2011, 12, 6267-6280. [CrossRef] [PubMed]

45. Chakraborty, C.; Sarkar, B.; Hsu, C.; Wen, Z.; Lin, C.; Shieh, P. Future prospects of nanoparticles on brain targeted drug delivery. J. Neuro-Oncol. 2009, 93, 285-286. [CrossRef] [PubMed]

46. Li, X.; Liu, B.; Li, X.L.; Li, Y.X.; Sun, M.Z.; Chen, D.Y.; Zhao, X.; Feng, X.Z. $\mathrm{SiO}_{2}$ nanoparticles change colour preference and cause Parkinson's-like behaviour in zebrafish. Sci. Rep. 2014, 4, 3810. [CrossRef] [PubMed]

47. Zhang, W.; Sun, X.; Chen, L.; Lin, K.F.; Dong, Q.X.; Huang, C.J.; Fu, R.B.; Zhu, J. Toxicological effect of joint cadmium selenium quantum dots and copper ion exposure on zebrafish. Environ. Toxicol. Chem. 2012, 31, 2117-2123. [CrossRef] [PubMed] 
48. Sheng, L.; Wang, L.; Su, M.; Zhao, X.; Hu, R.; Yu, X.; Hong, J.; Liu, D.; Xu, B.; Zhu, Y. Mechanism of TiO 2 nanoparticle-induced neurotoxicity in zebrafish (Danio rerio). Environ. Toxicol. 2016, 31, 163-175. [CrossRef] [PubMed]

49. Peravali, R.; Gehrig, J.; Giselbrecht, S.; Lütjohann, D.S.; Hadzhiev, Y.; Müller, F.; Liebel, U. Automated feature detection and imaging for high-resolution screening of zebrafish embryos. Biotechniques 2011, 50, 319-324. [CrossRef] [PubMed]

50. Boran, H.; Boyle, D.; Altinok, I.; Patsiou, D.; Henry, T.B. Aqueous $\mathrm{Hg}(2+)$ associates with $\mathrm{TiO}_{2}$ nanoparticles according to particle size, changes particle agglomeration, and becomes less bioavailable to zebrafish. Aquat. Toxicol. 2016, 174, 242-246. [CrossRef] [PubMed]

51. Browning, L.M.; Huang, T.; Xu, X.-H.N. Real-time in vivo imaging of size-dependent transport and toxicity of gold nanoparticles in zebrafish embryos using single nanoparticle plasmonic spectroscopy. Interface Focus 2013, 3, 20120098. [CrossRef] [PubMed]

52. Lin, S.; Zhao, Y.; Nel, A.E.; Lin, S. Zebrafish: An in vivo model for nano EHS studies. Small 2013, 9, 1608-1618. [CrossRef] [PubMed]

53. Knudsen, T.B.; Kavlock, R.J.; Daston, G.P.; Stedman, D.; Hixon, M.; Kim, J.H. Developmental toxicity testing for safety assessment: New approaches and technologies. Birth Defects Res. Part B Dev. Reprod. Toxicol. 2011, 92, 413-420. [CrossRef] [PubMed]

54. Roy, P.; Periasamy, A.P.; Lin, C.-Y.; Her, G.-M.; Chiu, W.-J.; Li, C.-L.; Shu, C.-L.; Huang, C.-C.; Liang, C.-T.; Chang, H.-T. Photoluminescent graphene quantum dots for in vivo imaging of apoptotic cells. Nanoscale 2015, 7, 2504-2510. [CrossRef] [PubMed]

55. Kang, Y.-F.; Li, Y.-H.; Fang, Y.-W.; Xu, Y.; Wei, X.-M.; Yin, X.-B. Carbon quantum dots for zebrafish fluorescence imaging. Sci. Rep. 2015, 5, 11835. [CrossRef] [PubMed]

56. de Jong, E.; Barenys, M.; Hermsen, S.A.; Verhoef, A.; Ossendorp, B.C.; Bessems, J.G.; Piersma, A.H. Comparison of the mouse Embryonic Stem cell Test, the rat Whole Embryo Culture and the Zebrafish Embryotoxicity Test as alternative methods for developmental toxicity testing of six 1,2,4-triazoles. Toxicol. Appl. Pharmacol. 2011, 253, 103-111. [CrossRef] [PubMed]

57. Beker van Woudenberg, A.; Wolterbeek, A.; Te Brake, L.; Snel, C.; Menke, A.; Rubingh, C.; de Groot, D.; Kroese, D. A category approach to predicting the developmental (neuro) toxicity of organotin compounds: The value of the zebrafish (Danio rerio) embryotoxicity test (ZET). Reprod. Toxicol. 2013, 41, 35-44. [CrossRef] [PubMed]

58. Ducharme, N.A.; Reif, D.M.; Gustafsson, J.A.; Bondesson, M. Comparison of toxicity values across zebrafish early life stages and mammalian studies: Implications for chemical testing. Reprod. Toxicol. 2015, 55, 3-10. [CrossRef] [PubMed]

59. Parng, C.; Seng, W.L.; Semino, C.; McGrath, P. Zebrafish: A preclinical model for drug screening. Assay Drug Dev. Technol. 2002, 1, 41-48. [CrossRef] [PubMed]

60. Scholz, S.; Ortmann, J.; Kluver, N.; Leonard, M. Extensive review of fish embryo acute toxicities for the prediction of GHS acute systemic toxicity categories. Regul. Toxicol. Pharmacol. 2014, 69, 572-579. [CrossRef] [PubMed]

61. Brannen, K.C.; Panzica-Kelly, J.M.; Danberry, T.L.; Augustine-Rauch, K.A. Development of a zebrafish embryo teratogenicity assay and quantitative prediction model. Birth Defects Res. B Dev. Reprod. Toxicol. 2010, 89, 66-77. [CrossRef] [PubMed]

62. Ducharme, N.A.; Peterson, L.E.; Benfenati, E.; Reif, D.; McCollum, C.W.; Gustafsson, J.A.; Bondesson, M. Meta-analysis of toxicity and teratogenicity of 133 chemicals from zebrafish developmental toxicity studies. Reprod. Toxicol. 2013, 41, 98-108. [CrossRef] [PubMed]

63. OECD. Guideline for Testing of Chemicals. Test No. 236: Fish Embryo Acute Toxicity (FET) Test; OECD: Paris, France, 2013.

64. OECD. Guideline for Testing of Chemicals. Test No. 215: Fish, Juvenile Growth Test; OECD: Paris, France, 2000.

65. OECD. Guideline for Testing of Chemicals. Test No. 2013: Fish, Acute Toxicity Test; OECD: Paris, France, 1992.

66. Busquet, F.; Strecker, R.; Rawlings, J.M.; Belanger, S.E.; Braunbeck, T.; Carr, G.J.; Cenijn, P.; Fochtman, P.; Gourmelon, A.; Hubler, N.; et al. OECD validation study to assess intra- and inter-laboratory reproducibility of the zebrafish embryo toxicity test for acute aquatic toxicity testing. Regul. Toxicol. Pharmacol. 2014, 69, 496-511. [CrossRef] [PubMed] 
67. Lammer, E.; Carr, G.J.; Wendler, K.; Rawlings, J.M.; Belanger, S.E.; Braunbeck, T. Is the fish embryo toxicity test (FET) with the zebrafish (Danio rerio) a potential alternative for the fish acute toxicity test? Comp. Biochem. Physiol. C Toxicol. Pharmacol. 2009, 149, 196-209. [CrossRef] [PubMed]

68. Belanger, S.E.; Rawlings, J.M.; Carr, G.J. Use of fish embryo toxicity tests for the prediction of acute fish toxicity to chemicals. Environ. Toxicol. Chem. 2013, 32, 1768-1783. [CrossRef] [PubMed]

69. Basnet, R.M.; Guarienti, M.; Memo, M. Zebrafish embryo as an in vivo model for behavioral and pharmacological characterization of methylxanthine drugs. Int. J. Mol. Sci. 2017, 18. [CrossRef] [PubMed]

70. Lee, K.J.; Browning, L.M.; Nallathamby, P.D.; Desai, T.; Cherukuri, P.K.; Xu, X.-H.N. In vivo quantitative study of sized-dependent transport and toxicity of single silver nanoparticles using zebrafish embryos. Chem. Res. Toxicol. 2012, 25, 1029-1046. [CrossRef] [PubMed]

71. Jang, G.H.; Hwang, M.P.; Kim, S.Y.; Jang, H.S.; Lee, K.H. A systematic in-vivo toxicity evaluation of nanophosphor particles via zebrafish models. Biomaterials 2014, 35, 440-449. [CrossRef] [PubMed]

72. Kovrižnych, J.A.; Sotníková, R.; Zeljenková, D.; Rollerová, E.; Szabová, E.; Wimmerová, S. Acute toxicity of 31 different nanoparticles to zebrafish (Danio rerio) tested in adulthood and in early life stages-Comparative study. Interdiscip. Toxicol. 2013, 6, 67-73. [CrossRef] [PubMed]

73. Griffitt, R.J.; Weil, R.; Hyndman, K.A.; Denslow, N.D.; Powers, K.; Taylor, D.; Barber, D.S. Exposure to copper nanoparticles causes gill injury and acute lethality in zebrafish (Danio rerio). Environ. Sci. Technol. 2007, 41, 8178-8186. [CrossRef] [PubMed]

74. Caceres-Velez, P.R.; Fascineli, M.L.; Sousa, M.H.; Grisolia, C.K.; Yate, L.; de Souza, P.E.N.; Estrela-Lopis, I.; Moya, S.; Azevedo, R.B. Humic acid attenuation of silver nanoparticle toxicity by ion complexation and the formation of a $\mathrm{Ag}(3+)$ coating. J. Hazard. Mater. 2018, 353, 173-181. [CrossRef] [PubMed]

75. Zhang, W.; Lin, K.; Miao, Y.; Dong, Q.; Huang, C.; Wang, H.; Guo, M.; Cui, X. Toxicity assessment of zebrafish following exposure to CdTe QDs. J. Hazard. Mater. 2012, 213-214, 413-420. [CrossRef] [PubMed]

76. Wehmas, L.C.; Anders, C.; Chess, J.; Punnoose, A.; Pereira, C.B.; Greenwood, J.A.; Tanguay, R.L. Comparative metal oxide nanoparticle toxicity using embryonic zebrafish. Toxicol. Rep. 2015, 2, 702-715. [CrossRef] [PubMed]

77. Zhu, X.; Zhu, L.; Duan, Z.; Qi, R.; Li, Y.; Lang, Y. Comparative toxicity of several metal oxide nanoparticle aqueous suspensions to Zebrafish (Danio rerio) early developmental stage. J. Environ. Sci. Health Part A 2008, 43, 278-284. [CrossRef] [PubMed]

78. Ghobadian, M.; Nabiuni, M.; Parivar, K.; Fathi, M.; Pazooki, J. Toxic effects of magnesium oxide nanoparticles on early developmental and larval stages of zebrafish (Danio rerio). Ecotoxicol. Environ. Saf. 2015, 122, 260-267. [CrossRef] [PubMed]

79. Kovriznych, J.A.; Sotnikova, R.; Zeljenkova, D.; Rollerova, E.; Szabova, E. Long-term (30 days) toxicity of $\mathrm{NiO}$ nanoparticles for adult zebrafish Danio rerio. Interdiscip. Toxicol. 2014, 7, 23-26. [CrossRef] [PubMed]

80. Kumari, P.; Panda, P.K.; Jha, E.; Kumari, K.; Nisha, K.; Mallick, M.A.; Verma, S.K. Mechanistic insight to ROS and apoptosis regulated cytotoxicity inferred by green synthesized $\mathrm{CuO}$ nanoparticles from Calotropis gigantea to embryonic zebrafish. Sci. Rep. 2017, 7, 16284. [CrossRef] [PubMed]

81. Zhu, X.; Zhu, L.; Li, Y.; Duan, Z.; Chen, W.; Alvarez, P.J. Developmental toxicity in zebrafish (Danio rerio) embryos after exposure to manufactured nanomaterials: Buckminsterfullerene aggregates (nC60) and fullerol. Environ. Toxicol. Chem. 2007, 26, 976-979. [CrossRef] [PubMed]

82. Cheng, J.; Flahaut, E.; Cheng, S.H. Effect of carbon nanotubes on developing zebrafish (Danio rerio) embryos. Environ. Toxicol. Chem. 2007, 26, 708-716. [CrossRef] [PubMed]

83. Huang, X.; El-Sayed, I.H.; Qian, W.; El-Sayed, M.A. Cancer cell imaging and photothermal therapy in the near-infrared region by using gold nanorods. J. Am. Chem. Soc. 2006, 128, 2115-2120. [CrossRef] [PubMed]

84. Dykman, L.; Khlebtsov, N. Gold nanoparticles in biology and medicine: Recent advances and prospects. Acta Nat. 2011, 3, 34-55.

85. Goodman, C.M.; McCusker, C.D.; Yilmaz, T.; Rotello, V.M. Toxicity of gold nanoparticles functionalized with cationic and anionic side chains. Bioconjugate Chem. 2004, 15, 897-900. [CrossRef] [PubMed]

86. Gerber, A.; Bundschuh, M.; Klingelhofer, D.; Groneberg, D.A. Gold nanoparticles: Recent aspects for human toxicology. J. Occup. Med. Toxicol. 2013, 8, 32. [CrossRef] [PubMed]

87. Geffroy, B.; Ladhar, C.; Cambier, S.; Treguer-Delapierre, M.; Brèthes, D.; Bourdineaud, J.-P. Impact of dietary gold nanoparticles in zebrafish at very low contamination pressure: The role of size, concentration and exposure time. Nanotoxicology 2012, 6, 144-160. [CrossRef] [PubMed] 
88. Dedeh, A.; Ciutat, A.; Treguer-Delapierre, M.; Bourdineaud, J.-P. Impact of gold nanoparticles on zebrafish exposed to a spiked sediment. Nanotoxicology 2015, 9, 71-80. [CrossRef] [PubMed]

89. Dayal, N.; Singh, D.; Patil, P.; Thakur, M.; Vanage, G.; Joshi, D. Effect of bioaccumulation of gold nanoparticles on ovarian morphology of female zebrafish (Danio rerio). World J. Pathol. 2017, 6, 1.

90. Truong, L.; Saili, K.S.; Miller, J.M.; Hutchison, J.E.; Tanguay, R.L. Persistent adult zebrafish behavioral deficits results from acute embryonic exposure to gold nanoparticles. Comp. Biochem. Physiol. Part C Toxicol. Pharmacol. 2012, 155, 269-274. [CrossRef] [PubMed]

91. Sangabathuni, S.; Murthy, R.V.; Chaudhary, P.M.; Subramani, B.; Toraskar, S.; Kikkeri, R. Mapping the glyco-gold nanoparticles of different shapes: Toxicity, biodistribution and sequestration in adult zebrafish. Sci. Rep. 2017, 7, 4239. [CrossRef] [PubMed]

92. Harper, B.; Sinche, F.; Wu, R.H.; Gowrishankar, M.; Marquart, G.; Mackiewicz, M.; Harper, S.L. The impact of surface ligands and synthesis method on the toxicity of glutathione-coated gold nanoparticles. Nanomaterials 2014, 4, 355-371. [CrossRef] [PubMed]

93. Ginzburg, A.L.; Truong, L.; Tanguay, R.L.; Hutchison, J.E. Synergistic toxicity produced by mixtures of biocompatible gold nanoparticles and widely used surfactants. ACS Nano 2018, 12, 5312-5322. [CrossRef] [PubMed]

94. Czupryna, J.; Tsourkas, A. Suicide gene delivery by calcium phosphate nanoparticles: A novel method of targeted therapy for gastric cancer. Cancer Biol. Ther. 2006, 5, 1691-1692. [CrossRef] [PubMed]

95. Yoon, K.-Y.; Byeon, J.H.; Park, J.-H.; Hwang, J. Susceptibility constants of Escherichia coli and Bacillus subtilis to silver and copper nanoparticles. Sci. Total Environ. 2007, 373, 572-575. [CrossRef] [PubMed]

96. Jin, S.; Ye, K. Nanoparticle-mediated drug delivery and gene therapy. Biotechnol. Prog. 2007, $23,32-41$. [CrossRef] [PubMed]

97. Yoo, M.H.; Rah, Y.C.; Choi, J.; Park, S.; Park, H.-C.; Oh, K.H.; Lee, S.H.; Kwon, S.-Y. Embryotoxicity and hair cell toxicity of silver nanoparticles in zebrafish embryos. Int. J. Pediat. Otorhinolaryngol. 2016, 83, 168-174. [CrossRef] [PubMed]

98. Xia, G.; Liu, T.; Wang, Z.; Hou, Y.; Dong, L.; Zhu, J.; Qi, J. The effect of silver nanoparticles on zebrafish embryonic development and toxicology. Artif. Cells Nanomed. Biotechnol. 2016, 44, 1116-1121. [CrossRef] [PubMed]

99. Bar-Ilan, O.; Albrecht, R.M.; Fako, V.E.; Furgeson, D.Y. Toxicity assessments of multisized gold and silver nanoparticles in zebrafish embryos. Small 2009, 5, 1897-1910. [CrossRef] [PubMed]

100. Xin, Q.; Rotchell, J.M.; Cheng, J.; Yi, J.; Zhang, Q. Silver nanoparticles affect the neural development of zebrafish embryos. J. Appl. Toxicol. 2015, 35, 1481-1492. [CrossRef] [PubMed]

101. Lee, K.J.; Browning, L.M.; Nallathamby, P.D.; Xu, X.-H.N. Study of charge-dependent transport and toxicity of peptide-functionalized silver nanoparticles using zebrafish embryos and single nanoparticle plasmonic spectroscopy. Chem. Res. Toxicol. 2013, 26, 904-917. [CrossRef] [PubMed]

102. George, S.; Lin, S.; Ji, Z.; Thomas, C.R.; Li, L.; Mecklenburg, M.; Meng, H.; Wang, X.; Zhang, H.; Xia, T. Surface defects on plate-shaped silver nanoparticles contribute to its hazard potential in a fish gill cell line and zebrafish embryos. ACS Nano 2012, 6, 3745-3759. [CrossRef] [PubMed]

103. Abramenko, N.B.; Demidova, T.B.; Abkhalimov, EV.; Ershov, B.G.; Krysanov, E.Y.; Kustov, L.M. Ecotoxicity of different-shaped silver nanoparticles: Case of zebrafish embryos. J. Hazard. Mater. 2018, 347, 89-94. [CrossRef] [PubMed]

104. Devi, G.P.; Ahmed, K.B.A.; Varsha, M.S.; Shrijha, B.; Lal, K.S.; Anbazhagan, V.; Thiagarajan, R. Sulfidation of silver nanoparticle reduces its toxicity in zebrafish. Aquat. Toxicol. 2015, 158, 149-156. [CrossRef] [PubMed]

105. George, S.; Gardner, H.; Seng, E.K.; Chang, H.; Wang, C.; Yu Fang, C.H.; Richards, M.; Valiyaveettil, S.; Chan, W.K. Differential effect of solar light in increasing the toxicity of silver and titanium dioxide nanoparticles to a fish cell line and zebrafish embryos. Environ. Sci. Technol. 2014, 48, 6374-6382. [CrossRef] [PubMed]

106. Bruchez, M.; Moronne, M.; Gin, P.; Weiss, S.; Alivisatos, A.P. Semiconductor nanocrystals as fluorescent biological labels. Science 1998, 281, 2013-2016. [CrossRef] [PubMed]

107. Wang, D.; He, J.; Rosenzweig, N.; Rosenzweig, Z. Superparamagnetic $\mathrm{Fe}_{2} \mathrm{O}_{3}$ beads-CdSe/ZnS quantum dots core-shell nanocomposite particles for cell separation. Nano Lett. 2004, 4, 409-413. [CrossRef]

108. Yong, K.-T.; Law, W.-C.; Hu, R.; Ye, L.; Liu, L.; Swihart, M.T.; Prasad, P.N. Nanotoxicity assessment of quantum dots: From cellular to primate studies. Chem. Soc. Rev. 2013, 42, 1236-1250. [CrossRef] [PubMed] 
109. Rieger, S.; Kulkarni, R.P.; Darcy, D.; Fraser, S.E.; Köster, R.W. Quantum dots are powerful multipurpose vital labeling agents in zebrafish embryos. Dev. Dyn. 2005, 234, 670-681. [CrossRef] [PubMed]

110. de Keijzer, M. The history of modern synthetic inorganic and organic artists' pigments. In Contibutions to Conservation: Research Conservation at Netherlands Institute for Cultural Heritage (ICN); James and James: London, UK, 2001.

111. Weir, A.; Westerhoff, P.; Fabricius, L.; Hristovski, K.; von Goetz, N. Titanium dioxide nanoparticles in food and personal care products. Environ. Sci. Technol. 2012, 46, 2242-2250. [CrossRef] [PubMed]

112. Wang, Y.-J.; He, Z.-Z.; Fang, Y.-W.; Xu, Y.; Chen, Y.-N.; Wang, G.-Q.; Yang, Y.-Q.; Yang, Z.; Li, Y.-H. Effect of titanium dioxide nanoparticles on zebrafish embryos and developing retina. Int. J. Ophthalmol. 2014, 7, 917-923. [PubMed]

113. Samaee, S.-M.; Rabbani, S.; Jovanović, B.; Mohajeri-Tehrani, M.R.; Haghpanah, V. Efficacy of the hatching event in assessing the embryo toxicity of the nano-sized $\mathrm{TiO}_{2}$ particles in zebrafish: A comparison between two different classes of hatching-derived variables. Ecotoxicol. Environ. Saf. 2015, 116, 121-128. [CrossRef] [PubMed]

114. Clemente, Z.; Castro, V.; Moura, M.; Jonsson, C.; Fraceto, L. Toxicity assessment of $\mathrm{TiO}_{2}$ nanoparticles in zebrafish embryos under different exposure conditions. Aquat. Toxicol. 2014, 147, 129-139. [CrossRef] [PubMed]

115. Bar-Ilan, O.; Louis, K.M.; Yang, S.P.; Pedersen, J.A.; Hamers, R.J.; Peterson, R.E.; Heideman, W. Titanium dioxide nanoparticles produce phototoxicity in the developing zebrafish. Nanotoxicology 2012, 6, 670-679. [CrossRef] [PubMed]

116. Chen, J.; Dong, X.; Xin, Y.; Zhao, M. Effects of titanium dioxide nano-particles on growth and some histological parameters of zebrafish (Danio rerio) after a long-term exposure. Aquat. Toxicol. 2011, 101, 493-499. [CrossRef] [PubMed]

117. Chen, T.-H.; Lin, C.-Y.; Tseng, M.-C. Behavioral effects of titanium dioxide nanoparticles on larval zebrafish (Danio rerio). Mar. Pollut. Bull. 2011, 63, 303-308. [CrossRef] [PubMed]

118. Palaniappan, P.R.; Pramod, K. The effect of titanium dioxide on the biochemical constituents of the brain of Zebrafish (Danio rerio): An FT-IR study. Spectrochim. Acta Part A Mol. Biomol. Spect. 2011, 79, $206-212$. [CrossRef] [PubMed]

119. Kteeba, S.M.; El-Adawi, H.I.; El-Rayis, O.A.; El-Ghobashy, A.E.; Schuld, J.L.; Svoboda, K.R.; Guo, L. Zinc oxide nanoparticle toxicity in embryonic zebrafish: Mitigation with different natural organic matter. Environ. Pollut. 2017, 230, 1125-1140. [CrossRef] [PubMed]

120. Ong, K.J.; Zhao, X.; Thistle, M.E.; MacCormack, T.J.; Clark, R.J.; Ma, G.; Martinez-Rubi, Y.; Simard, B.; Loo, J.S.C.; Veinot, J.G. Mechanistic insights into the effect of nanoparticles on zebrafish hatch. Nanotoxicology 2014, 8, 295-304. [CrossRef] [PubMed]

121. Hua, J.; Vijver, M.G.; Richardson, M.K.; Ahmad, F.; Peijnenburg, W.J. Particle-specific toxic effects of differently shaped zinc oxide nanoparticles to zebrafish embryos (Danio rerio). Environ. Toxicol. Chem. 2014, 33, 2859-2868. [CrossRef] [PubMed]

122. Liu, Y.; Liu, B.; Feng, D.; Gao, C.; Wu, M.; He, N.; Yang, X.; Li, L.; Feng, X. A progressive approach on zebrafish toward sensitive evaluation of nanoparticles' toxicity. Integr. Biol. 2012, 4, 285-291. [CrossRef] [PubMed]

123. Lin, S.; Zhao, Y.; Xia, T.; Meng, H.; Ji, Z.; Liu, R.; George, S.; Xiong, S.; Wang, X.; Zhang, H. High content screening in zebrafish speeds up hazard ranking of transition metal oxide nanoparticles. ACS Nano 2011, 5, 7284-7295. [CrossRef] [PubMed]

124. Cha, C.; Shin, S.R.; Annabi, N.; Dokmeci, M.R.; Khademhosseini, A. Carbon-based nanomaterials: Multifunctional materials for biomedical engineering. ACS Nano 2013, 7, 2891-2897. [CrossRef] [PubMed]

125. Kumar, V.; Toffoli, G.; Rizzolio, F. Fluorescent carbon nanoparticles in medicine for cancer therapy. ACS Med. Chem. Lett. 2013, 4, 1012-1013. [CrossRef] [PubMed]

126. Kroto, H.W.; Heath, J.R.; O’Brien, S.C.; Curl, R.F.; Smalley, R.E. C60: Buckminsterfullerene. Nature 1985, 318, 162-163. [CrossRef]

127. Montellano, A.; Da Ros, T.; Bianco, A.; Prato, M. Fullerene C(60) as a multifunctional system for drug and gene delivery. Nanoscale 2011, 3, 4035-4041. [CrossRef] [PubMed]

128. Partha, R.; Conyers, J.L. Biomedical applications of functionalized fullerene-based nanomaterials. Int. J. Nanomed. 2009, 4, 261-275. 
129. Usenko, C.Y.; Harper, S.L.; Tanguay, R.L. In vivo evaluation of carbon fullerene toxicity using embryonic zebrafish. Carbon 2007, 45, 1891-1898. [CrossRef] [PubMed]

130. Beuerle, F.; Witte, P.; Hartnagel, U.; Lebovitz, R.; Parng, C.; Hirsch, A. Cytoprotective activities of water-soluble fullerenes in zebrafish models. J. Exp. Nanosci. 2007, 2, 147-170. [CrossRef]

131. Kuznetsova, G.; Larina, O.; Petushkova, N.; Kisrieva, Y.S.; Samenkova, N.; Trifonova, O.; Karuzina, I.; Ipatova, O.; Zolotaryov, K.; Romashova, Y.A. Effects of fullerene C60 on proteomic profile of Danio rerio fish embryos. Bull. Exp. Biol. Med. 2014, 156, 694-698. [CrossRef] [PubMed]

132. Usenko, C.Y.; Harper, S.L.; Tanguay, R.L. Fullerene C60 exposure elicits an oxidative stress response in embryonic zebrafish. Toxicol. Appl. Pharmacol. 2008, 229, 44-55. [CrossRef] [PubMed]

133. Daroczi, B.; Kari, G.; McAleer, M.F.; Wolf, J.C.; Rodeck, U.; Dicker, A.P. In vivo radioprotection by the fullerene nanoparticle DF-1 as assessed in a zebrafish model. Clin. Cancer Res. 2006, 12, 7086-7091. [CrossRef] [PubMed]

134. d'Amora, M.; Rodio, M.; Bartelmess, J.; Sancataldo, G.; Brescia, R.; Cella Zanacchi, F.; Diaspro, A.; Giordani, S. Biocompatibility and biodistribution of functionalized carbon nano-onions (f-CNOs) in a vertebrate model. Sci. Rep. 2016, 6, 33923. [CrossRef] [PubMed]

135. He, H.; Pham-Huy, L.A.; Dramou, P.; Xiao, D.; Zuo, P.; Pham-Huy, C. Carbon nanotubes: Applications in pharmacy and medicine. BioMed Res. Int. 2013, 2013, 578290. [CrossRef] [PubMed]

136. Liu, Z.; Tabakman, S.; Welsher, K.; Dai, H. Carbon nanotubes in biology and medicine: In vitro and in vivo detection, imaging and drug delivery. Nano Res. 2009, 2, 85-120. [CrossRef] [PubMed]

137. Wang, R.; Alicea, N.M.; Lee, M., Jr.; Deutsch, D.; Miadzvedskaya, L.; Braun, E.; Pantano, P.; Harper, S.; Draper, R. Toxicity assessment and bioaccumulation in zebrafish embryos exposed to carbon nanotubes suspended in Pluronic(R) F-108. Nanotoxicology 2016, 10, 689-698. [CrossRef] [PubMed]

138. Girardi, F.A.; Bruch, G.E.; Peixoto, C.S.; Dal Bosco, L.; Sahoo, S.K.; Gonçalves, C.O.; Santos, A.P.; Furtado, C.A.; Fantini, C.; Barros, D.M. Toxicity of single-wall carbon nanotubes functionalized with polyethylene glycol in zebrafish (Danio rerio) embryos. J. Appl. Toxicol. 2017, 37, 214-221. [CrossRef] [PubMed]

139. Cheng, J.; Cheng, S.H. Influence of carbon nanotube length on toxicity to zebrafish embryos. Int. J. Nanomed. 2012, 7, 3731-3739. [CrossRef] [PubMed]

140. de Souza Filho, J.; Matsubara, E.Y.; Franchi, L.P.; Martins, I.P.; Rivera, L.M.R.; Rosolen, J.M.; Grisolia, C.K. Evaluation of carbon nanotubes network toxicity in zebrafish (Danio rerio) model. Environ. Res. 2014, 134, 9-16. [CrossRef] [PubMed]

141. Maes, H.M.; Stibany, F.; Giefers, S.; Daniels, B.; Deutschmann, B.; Baumgartner, W.; Schäffer, A. Accumulation and distribution of multiwalled carbon nanotubes in zebrafish (Danio rerio). Environ. Sci. Technol. 2014, 48, 12256-12264. [CrossRef] [PubMed]

142. Li, J.; Ying, G.-G.; Jones, K.C.; Martin, F.L. Real-world carbon nanoparticle exposures induce brain and gonadal alterations in zebrafish (Danio rerio) as determined by biospectroscopy techniques. Analyst 2015, 140, 2687-2695. [CrossRef] [PubMed]

143. Baker, S.N.; Baker, G.A. Luminescent carbon nanodots: Emergent nanolights. Angew. Chem. Int. Ed. 2010, 49, 6726-6744. [CrossRef] [PubMed]

144. Pan, D.; Zhang, J.; Li, Z.; Wu, M. Hydrothermal route for cutting graphene sheets into blue-luminescent graphene quantum dots. Adv. Mater. 2010, 22, 734-738. [CrossRef] [PubMed]

145. Shen, J.; Zhu, Y.; Chen, C.; Yang, X.; Li, C. Facile preparation and upconversion luminescence of graphene quantum dots. Chem. Commun. 2011, 47, 2580-2582. [CrossRef] [PubMed]

146. Zheng, X.T.; Ananthanarayanan, A.; Luo, K.Q.; Chen, P. Glowing graphene quantum dots and carbon dots: Properties, syntheses, and biological applications. Small 2015, 11, 1620-1636. [CrossRef] [PubMed]

147. Peng, J.; Gao, W.; Gupta, B.K.; Liu, Z.; Romero-Aburto, R.; Ge, L.; Song, L.; Alemany, L.B.; Zhan, X.; Gao, G. Graphene quantum dots derived from carbon fibers. Nano Lett. 2012, 12, 844-849. [CrossRef] [PubMed]

148. Shen, J.; Zhu, Y.; Yang, X.; Zong, J.; Zhang, J.; Li, C. One-pot hydrothermal synthesis of graphene quantum dots surface-passivated by polyethylene glycol and their photoelectric conversion under near-infrared light. New J. Chem. 2012, 36, 97-101. [CrossRef]

149. Wang, Z.; Xia, J.; Zhou, C.; Via, B.; Xia, Y.; Zhang, F.; Li, Y.; Xia, L.; Tang, J. Synthesis of strongly green-photoluminescent graphene quantum dots for drug carrier. Colloids Surf. B Biointerfaces 2013, 112, 192-196. [CrossRef] [PubMed] 
150. Liu, C.; Zhang, P.; Zhai, X.; Tian, F.; Li, W.; Yang, J.; Liu, Y.; Wang, H.; Wang, W.; Liu, W. Nano-carrier for gene delivery and bioimaging based on carbon dots with PEI-passivation enhanced fluorescence. Biomaterials 2012, 33, 3604-3613. [CrossRef] [PubMed]

151. Wang, X.; Sun, X.; Lao, J.; He, H.; Cheng, T.; Wang, M.; Wang, S.; Huang, F. Multifunctional graphene quantum dots for simultaneous targeted cellular imaging and drug delivery. Colloids Surf. B Biointerfaces 2014, 122, 638-644. [CrossRef] [PubMed]

152. Zhou, J.; Booker, C.; Li, R.; Zhou, X.; Sham, T.-K.; Sun, X.; Ding, Z. An electrochemical avenue to blue luminescent nanocrystals from multiwalled carbon nanotubes (MWCNTs). J. Am. Chem. Soc. 2007, 129, 744-745. [CrossRef] [PubMed]

153. Bhunia, S.K.; Saha, A.; Maity, A.R.; Ray, S.C.; Jana, N.R. Carbon nanoparticle-based fluorescent bioimaging probes. Sci. Rep. 2013, 3, 1473. [CrossRef] [PubMed]

154. Wang, X.; Cao, L.; Yang, S.T.; Lu, F.; Meziani, M.J.; Tian, L.; Sun, K.W.; Bloodgood, M.A.; Sun, Y.P. Bandgap-like strong fluorescence in functionalized carbon nanoparticles. Angew. Chem. Int. Ed. 2010, 122, 5438-5442. [CrossRef]

155. Khajuria, D.K.; Kumar, V.B.; Karasik, D.; Gedanken, A. Fluorescent nanoparticles with tissue dependent affinity for live zebrafish imaging. ACS Appl. Mat. Interfaces 2017, 22, 18557-18565. [CrossRef] [PubMed]

156. McWilliams, A. The Maturing Nanotechnology Market: Products and Applications; BCC Research: Wellesley, MA, USA, 2016.

(C) 2018 by the authors. Licensee MDPI, Basel, Switzerland. This article is an open access article distributed under the terms and conditions of the Creative Commons Attribution (CC BY) license (http://creativecommons.org/licenses/by/4.0/). 